\title{
The Behaviour of Tanned Erythrocytes in Various Haemagglutination Systems
}

\author{
By G. A. GARABEDIAN \\ Department of Bacteriology and Virology, \\ American University of Beirut, Beirut, Lebanon
}

(Received 31 March 1964)

\begin{abstract}
SUMMARY
Erythrocytes from various species of animals were tanned by exposure to $1 / 20,000$ tannic acid for $10 \mathrm{~min}$. at $37^{\circ}$, and were used in various haemagglutination systems together with untreated red cells as control. The titre of fresh human anti-AB serum was decreased from 4- to 64-fold when tested with tanned homologous red cells, while no decrease of titre was observed in commercially prepared sera of the same group under identical experimental conditions. The titre of anti-sheep red cell serum was not appreciably affected when tested with tanned sheep red cells, but there was a 2- to 4-fold increase in the agglutinin titres of myxoviruses (influenza, mumps) tested with tanned chick or sheep red cells. The haemagglutinin titres of West Nile and Sindbis viruses were not changed when tanned goose red cells were used instead of untreated red cells in haemagglutination tests. Human, guinea pig and fowl red cells did not become agglutinable by West Nile and Sindbis viruses after treatment with tannic acid. West Nile and Sindbis viruses agglutinated sheep red cells to low titres. These titres were twice as high when tanned red cells were used instead of untreated cells. There was a sharp drop in the titres of anti-human cell sera when tested with tanned human group $\mathbf{O}$ red cells. It is suggested that tannic acid may act on certain species of red cell to increase or decrease their agglutinability in the presence of immune serum.
\end{abstract}

\section{INTRODUCTION}

Alterations induced by tannic acid on the surface of erythrocytes (red cells) result in attainment by such treated cells of the ability to adsorb protein material and to agglutinate in the presence of specific immune serum (Boyden, 1951). This phenomenon, known as indirect haemagglutination, has been extensively used for detecting antibodies in bacterial, viral and parasitic diseases (Neter, 1956). However, relatively little work has been done to define the behaviour of tanned red cells in direct haemagglutination tests. In a report by Buckland \& Tyrrell (1963), changes induced in the agglutinability of red cells after treating them with a variety of substances, including formalin, papain, chymotrypsin, periodate, receptor-destroying enzyme and swine influenza virus, were described. Tannic acid was not included in these studies. Reports of other investigators (Brading, 1956; Hornung \& Baer, 1958), as to the extent of agglutinability of tannic acid-treated red cells in human ABO system, have been somewhat contradictory.

Because of the few and conflicting reports of direct haemagglutination with tanned red cells, the problem was thought worth investigating. The experiments 
reported here were done to study the behaviour of tanned red cells in various haemagglutination systems, and to learn whether the results obtained would provide any information as to the nature and diversity of receptor sites on the red cell surface. Studies on the effect of tannic acid on surface antigens of HeLa cells have been presented elsewhere (Garabedian \& Syverton, 1960).

\section{METHODS}

Tanning of erythrocytes. Blood was obtained in modified Alsever's solution (Bukantz, Rein \& Kent, 1946), and kept at $8^{\circ}$ for 3 days before use. Red cells were washed with $0.85 \% \mathrm{NaCl}$ solution and tanned by addition of $1 \mathrm{ml}$. packed cells to $19 \mathrm{ml}$. freshly prepared tannic acid (Merck) $1 / 20,000(\mathrm{w} / \mathrm{v})$ in $0 \cdot 85 \% \mathrm{NaCl}$ solution. For tanning the sheep red cells, for use in a sheep-anti-sheep red cell haemagglutination system, different concentrations of tannic acid, ranging from $1 / 1000-1 / 40,000$, were used. Red cell suspensions in the tannic acid were incubated at $37^{\circ}$ for $10 \mathrm{~min}$. with frequent agitation (Garabedian, Matossian \& Djanian, 1957), sedimented by centrifugation, washed with $\mathbf{0 . 8 5} \% \mathrm{NaCl}$ solution and diluted in the same solution to a concentration of $1 \%$ according to packed cell volume.

Direct haemagglutination tests. Anti-AB, anti-sheep red cell and anti-cellular titres in sera were determined by making serial dilutions of inactivated serum with $\mathbf{2} \%$ bovine albumin (Armour, fraction $\mathrm{V}$ ) in phosphate buffer saline ( $\mathrm{pH} \mathrm{7.0)}$, using $0.5 \mathrm{ml}$. volumes for each tube. To each dilution of serum, including the control tube, $0.12 \mathrm{ml}$. of a $1 \%$ suspension of washed red cells was added. Tubes were incubated at $37^{\circ}$ for $30 \mathrm{~min}$., after which they were placed at $4^{\circ}$ for the red cells to sediment. Readings were taken after gently mixing the contents of the tubes.

Myxovirus haemagglutination tests were done with infectious chick embryo allantoic fluids according to the standard technique described by Jensen (1956). Arthropod borne (arbo) virus haemagglutination tests were performed following the procedure described by Clarke \& Casals (1958). Dilutions of immune serum were made in $2 \%$ bovine albumin in buffered saline. This helped the even settling of the tanned red cells but did not interfere with the sensitivity of the test.

Anti-cellular sera. Anti-cellular sera were prepared by intravenous injection of rabbits with human cells (HeLa, KB, primary amnion, and continuous amnion) grown in yeast extract medium supplemented with $20 \%(\mathrm{v} / \mathrm{v})$ human serum. The cells were washed repeatedly with $0.85 \% \mathrm{NaCl}$ solution, scraped from glass and made into a suspension containing about $2 \times 10^{6}$ cells $/ \mathrm{ml}$., frozen and thawed repeatedly and freed from coarse sediment by centrifugation at $500 \mathrm{~g}$. Each rabbit received four injections of $2 \mathrm{ml}$. cell suspension at 4-day intervals. After 1 week the rabbits were given a fifth injection of $5 \times 10^{6}$ sonically-disrupted cells in Freund's adjuvant. The dose was distributed at various body sites subcutaneously and intramuscularly. None of the animals showed anaphylactic reactions. Blood was taken from the animals 10 days after the last injection, and the serum was stored at $-20^{\circ}$. Before use, samples of test sera were thawed and heated at $56^{\circ}$ for $20 \mathrm{~min}$. Control serum was collected from randomly selected uninjected rabbits.

Haemagglutination studies were made with the following systems: (1) anti-AB human serum .with human red cells; (2) anti-sheep red cell serum with sheep red 
cells; (3) myxoviruses with fowl and sheep red cells; (4) arboviruses with goose, fowl, human, guinea pig and sheep red cells; (5) anti-human cell serum with human red cells.

The human ABO system of haemagglutination was studied by using fresh human sera as well as commercially prepared anti-AB sera. For the sheep-anti-sheep red cell system, rabbit immune serum prepared against sheep red cells was used with sheep red cells. In myxovirus haemagglutination tests influenza $A$ and A1 strains, PR 8, FM 1, Denver; A 2 strain, Jap-305; B strain, Lee, and mumps virus were used as agglutinins against chick and sheep red cells. In arbovirus haemagglutination tests West Nile and Sindbis viruses were used as haemagglutinins with red cells obtained from goose, fowl, man, guinea pig and sheep. Finally, human group 0 red cells and anti-cellular sera prepared in the rabbit were used in direct haemagglutination tests (Brand \& Syverton, 1960). Both tanned and untreated red cells were used in all tests.

\section{RESULTS}

Titres of fresh human sera were decreased from 4- to 64-fold when tested with tanned homologous group $\mathbf{A}, \mathbf{B}$ and $\mathbf{A B}$ agglutinogens, while the decrease in titres was no more than 2-fold when commercially prepared sera were used in place of fresh serum in similar experiments (Table 1). These findings explain the discrepancy between the results of Brading (1956) and Hornung \& Baer (1958). The latter

Table 1. ABO system of haemagglutination using untreated and tanned human red cells

\begin{tabular}{|c|c|c|c|c|c|c|c|}
\hline \multirow{2}{*}{\multicolumn{2}{|c|}{ Human red cells }} & \multicolumn{4}{|c|}{$\begin{array}{c}\text { Serum designation and titre* } \\
\text { fresh serum }\end{array}$} & \multirow{2}{*}{\multicolumn{2}{|c|}{$\begin{array}{c}\text { Serum } \\
\text { designation } \\
\text { and titre } \\
\text { commercial serum } f\end{array}$}} \\
\hline & & \multicolumn{2}{|c|}{ Anti-A } & \multicolumn{2}{|c|}{ Anti-B } & & \\
\hline Group & Nature & 1 & 2 & $\mathbf{3}$ & 4 & Anti-A & Anti-B \\
\hline O & $\begin{array}{l}\text { Untreated } \\
\text { Tanned }\end{array}$ & - & - & - & - & - & - \\
\hline $\mathbf{A}$ & $\begin{array}{l}\text { Untreated } \\
\text { Tanned }\end{array}$ & $\begin{array}{r}128 \\
16\end{array}$ & 16 & $\overrightarrow{-}$ & - & $\begin{array}{r}128 \\
64\end{array}$ & - \\
\hline B & $\begin{array}{l}\text { Untreated } \\
\text { Tanned }\end{array}$ & - & - & $\underline{32}$ & 64 & - & $\begin{array}{l}64 \\
64\end{array}$ \\
\hline $\mathbf{A B}$ & $\begin{array}{l}\text { Untreated } \\
\text { Tanned }\end{array}$ & $\begin{array}{r}16 \\
4\end{array}$ & $\begin{array}{l}4 \\
-\end{array}$ & $\underline{16}$ & 32 & $\begin{array}{l}8 \\
4\end{array}$ & $\begin{array}{l}64 \\
32\end{array}$ \\
\hline & & $\begin{array}{l}* 1 \\
+1 \\
+1\end{array}$ & Pha & $\begin{array}{l}\text { m ti } \\
\text { ical }\end{array}$ & 113 & & \\
\hline
\end{tabular}

investigators used commercially prepared sera for their determinations and observed no diminution in titre when tested with tanned red cells. It is possible that commercial serum, which may have been prepared by injecting men with $\mathbf{A}$ and $\mathbf{B}$ substances, contains accessory factors capable of reacting with tanned red cells. This property may be absent in fresh serum. Nevertheless, the exact mechanism of this phenomenon is not clear.

While 1/1000 and 1/2000 concentrations of tannic acid produced complete or 
partial haemolysis and clumping of sheep red cells, and could not be used in tes ts other concentrations, in the range of $1 / 5000$ to $1 / 40,000$, did not have any appreciable effect on the agglutinability of sheep red cells when these cells were tested with anti-sheep red cell serum prepared in the rabbit (Table 2). Apparently the receptor site of action on the sheep red cells, unlike the human $\mathrm{AB}$ red cells, was not affected by any concentration of tannic acid used in this experiment.

Table 2. Effect of various concentrations of tannic acid on the agglutinability of sheep red cells with homologous immune rabbit serum

\begin{tabular}{|c|c|c|c|c|}
\hline \multirow{2}{*}{$\begin{array}{l}\text { Sheep red cells } \\
\text { treated with tannic } \\
\text { acid in } \\
\text { concentrations of: }\end{array}$} & \multicolumn{4}{|c|}{ Anti-sheep red cell rabbit serum titres } \\
\hline & $1 / 800$ & $1 / 1600$ & $1 / 3200$ & $1 / 6400$ \\
\hline $\begin{array}{l}1 / 1000 \\
1 / 2000\end{array}$ & \multicolumn{4}{|c|}{ haemolysis } \\
\hline $1 / 5000$ & + & + & \pm & - \\
\hline $1 / 10,000$ & + & + & $\overrightarrow{+}$ & - \\
\hline $1 / 20,000$ & + & + & \pm & - \\
\hline $1 / 40,000$ & + & + & \pm & - \\
\hline $\begin{array}{l}\text { heep red cells, } \\
\text { untreated }\end{array}$ & + & + & \pm & - \\
\hline
\end{tabular}

Table 3. Agglutinability of chick and sheep red cells with myxoviruses before and after treatment with tannic acid

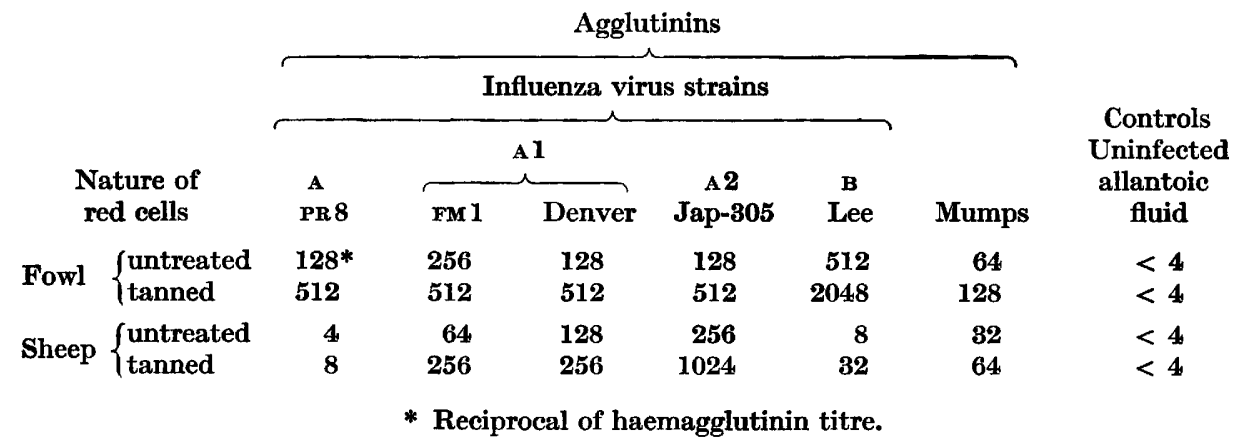

There was a 2- to 4-fold increase in myxovirus (influenza, mumps) titres, when tested with fowl or sheep tanned red cells (Table 3). This was possibly due to the removal by tannic acid from the red cells of certain elements which were masking the superficial receptor sites of red cells, with resulting exposure of deeper sites capable of reacting with viral haemagglutinins. It is also possible that a slight increase in titre of myxovirus haemagglutinins was due to a change in the surface potential of the tanned red cells. The low titres of influenza viruses $A$ and $B$ with sheep red cells as compared to high titres with other influenza viruses, A 1 or A 2, are worthy of consideration.

There was no change in haemagglutinin titres of West Nile and Sindbis viruses when tanned goose red cells were used in haemagglutination tests instead of untreated cells. Furthermore, fowl, human and guinea pig red cells did not become agglutinable by West Nile and Sindbis viruses after treatment with tannic acid. 
West Nile and Sindbis viruses agglutinated sheep red cells to low titres only. These titres were 2-fold higher when tanned red cells were used instead of untreated cells (Table 4).

Table 4. Agglutinability of red cells from various species of animal with arboviruses before and after treatment with tannic acid

\begin{tabular}{|c|c|c|c|c|c|}
\hline \multicolumn{2}{|c|}{ Nature of erythrocyte } & \multirow{2}{*}{$\begin{array}{c}\text { West Nile } \\
\text { virus } \\
\text { (pH 6.6) } \\
640 \\
640\end{array}$} & \multirow{2}{*}{ 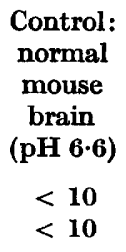 } & \multirow{2}{*}{$\begin{array}{c}\begin{array}{c}\text { Sindbis } \\
\text { virus } \\
\text { (pH 5·8) }\end{array} \\
\text { 320 } \\
320\end{array}$} & \multirow{2}{*}{$\begin{array}{c}\text { Control: } \\
\text { normal } \\
\text { mouse } \\
\text { brain } \\
\text { (pH 5.8) } \\
<10 \\
<10\end{array}$} \\
\hline Goose & $\left\{\begin{array}{l}\text { untreated } \\
\text { tanned }\end{array}\right.$ & & & & \\
\hline Fowl & $\left\{\begin{array}{l}\text { untreated } \\
\text { tanned }\end{array}\right.$ & $\begin{array}{l}<10 \\
<10\end{array}$ & $\begin{array}{l}<10 \\
<10\end{array}$ & $\begin{array}{l}<10 \\
<10\end{array}$ & $\begin{array}{l}<10 \\
<10\end{array}$ \\
\hline Human & $\left\{\begin{array}{l}\text { untreated } \\
\text { tanned }\end{array}\right.$ & $\begin{array}{l}<10 \\
<10\end{array}$ & $\begin{array}{l}<10 \\
<10\end{array}$ & $\begin{array}{l}<10 \\
<10\end{array}$ & $\begin{array}{l}<10 \\
<10\end{array}$ \\
\hline Guinea pig & $\left\{\begin{array}{l}\text { untreated } \\
\text { tanned }\end{array}\right.$ & $\begin{array}{l}<10 \\
<10\end{array}$ & $\begin{array}{l}<10 \\
<10\end{array}$ & $\begin{array}{l}<10 \\
<10\end{array}$ & $\begin{array}{l}<10 \\
<10\end{array}$ \\
\hline Sheep & $\left\{\begin{array}{l}\text { untreated } \\
\text { tanned }\end{array}\right.$ & $\begin{array}{l}40 \\
80\end{array}$ & $\begin{array}{l}<10 \\
<10\end{array}$ & $\begin{array}{l}10 \\
20\end{array}$ & $\begin{array}{l}<10 \\
<10\end{array}$ \\
\hline
\end{tabular}

Table 5. Haemagglutination of human group $O$ red cells with human anti-cellular serum

\begin{tabular}{lccccc} 
& \multicolumn{4}{c}{ Anti-cellular sera and titres } \\
\cline { 2 - 5 } $\begin{array}{c}\text { Nature of } \\
\text { red cells }\end{array}$ & Anti-HeLa & Anti-KB & $\begin{array}{c}\text { Anti- } \\
\text { amnion } \\
\text { (primary) }\end{array}$ & $\begin{array}{c}\text { Anti- } \\
\text { amnion } \\
\text { (continuous) }\end{array}$ & $\begin{array}{c}\text { Normal } \\
\text { rabbit }\end{array}$ \\
Untreated & $256^{*}$ & 64 & 64 & 64 & 8 \\
Tanned & 2 & $<2$ & $<2$ & 2 & 2 \\
& $*$ Reciprocal of serum titre.
\end{tabular}

That tanned HeLa cells lose at least a part of their surface antigens and, when coated on red cells, become non-reactive in indirect haemagglutination tests, was demonstrated earlier (Garabedian \& Syverton, 1960). In experiments reported here, the tanned red cells reacted very poorly with anti-cellular serum (Table 5). This was possibly due to the removal from or masking of certain surface antigens of the red cells by the tannic acid treatment. It was also noted that all four antihuman red cell sera reacted similarly by showing either total or drastic decrease of the original titre. This and previous experiments indicate that the action of tannic acid was mainly on human red cells, and only to a slight extent on sheep and chick red cells. A low titre in non-immune rabbit serum against human red cells should be noted. In some experiments irregular settling of erythrocytes, simulating a mild type of haemagglutination, was observed in tubes containing human group 0 tanned red cells with anti-HeLa serum. Nevertheless, unlike the haemagglutination observed in untreated cells, these erythrocytes were easily dispersed upon gentle shaking of the tubes. A satisfactory explanation for this peculiar phenomenon could not be postulated. 


\section{DISCUSSION}

The surface structure of the red cell is complex and far from being adequately studied. It has been described as composed of liproprotein (elinin) units located parallel to the cell surface and linked together with ether-extractable lipids. In addition protein (S protein) and some haemoglobin are thought to be associated with this structure (Moskowitz \& Calvin, 1952). Springer (1963) has presented an extensive review of work on cell surface antigens.

The reactions in various haemagglutination systems involve an interaction between haemagglutinins and a meshwork of various macromolecules of mucopolysaccharides, mucoproteins, phospholipids and other reactant groups located on the cell surface. Thus, an agent exposed to the intact red cell will react with these various determinant groups as well as with the haemoglobin, if it is capable of doing so. Brading (1956) presented evidence that tannic acid reacts with the iron on the surface of red cells. However, it is possible that beside this simple chemical union, tannic acid also combines with other structures of the red cells, resulting in masking or unmasking of receptors, altering their chemical structure partially or completely and/or changing the surface potential of the cell. For example, considering that $\mathrm{ABO}$ blood group activity resides in the 'elinin' fraction of the red cells (Moskowitz \& Calvin, 1952), it can be assumed that the action of tannic acid was directed towards this substance, as evidenced by a decrease in agglutinability of tanned $\mathrm{AB}$ red cells in the presence of homologous immune serum. It is possible that the decreased agglutinability of tanned group $O$ red cells in the presence of anticellular serum was also due to this same mechanism of action of tannic acid on the red cells. On the other hand it appears that the commercially prepared sera possessed additional factors capable of reacting with other receptors on the red cell surface not affected by tannic acid. It was further apparent that tannic acid had no appreciable effect on the neuraminic acid derivatives. This was shown by the fact that the agglutinability of tanned red cells was not decreased in the presence of myxoviruses. Contrariwise, a slight increase in titre in these tests was possibly due to a change in the surface potential of the red cells, brought about by the tannic acid treatment. Other agents acting on red cells bring about surface alterations which may be different from those caused by tannic acid (Buckland \& Tyrrell, 1963).

The work reported in this paper was supported in part by grant AI-03812 from the National Institutes of Health, U.S. Public Health Service.

\section{REFERENCES}

Boyden, S. V. (1951). The adsorption of proteins on erythrocytes treated with tannic acid and subsequent hemagglutination by antiprotein sera. J. exp. Med. 93, 107.

Brading, J. (1956). The use of tannic acid to link blood group substances to group $\mathrm{O}$ cells. Aust. J. exp. Biol. med. Sci. 34, 157.

Brand, K. G. \& Sxverton, J. T. (1960). Immunology of cultivated mammalian cells. I. Species specificity determined by hemagglutination. J. nat. Cancer Inst. 24, 1007.

Buckland, F. E. \& Tyrrel,, D. A. J. (1963). A comparative study of virus haemagglutinins. The stability of haemagglutinins and red cell receptors to certain physical and chemical treatments. J. gen. Microbiol. 32, 241. 
Bukantz, S. C., Rein, C. R. \& Kent, J. F. (1946). Studies in complement fixation. II. Preservation of sheep's blood in citrate dextrose mixtures (modified Alsever's solution) for use in the complement-fixation reaction. J. lab. clin. Med. 31, 394.

Clarke, D. H. \& Casals, J. (1958). Techniques for hemagglutination and hemagglutination-inhibition with arthropod-borne viruses. Am. J. trop. Med. Hyg. 7, 561.

Garabedian, G. A., Matossian, R. M. \& DJanian, A. Y. (1957). An indirect hemagglutination test for hydatid disease. J. Immun. 78, 269.

Garabedian, G. A. \& Syverton, J. T. (1960). Detection of anti-HeLa antibodies in rabbit antiserum by indirect hemagglutination. Proc. Soc. exp. Biol., N.Y. 105, 632.

Hornung, M. \& BaEr, H. (1958). Effect of tannic acid and adsorbed purified blood group substances on human erythrocytes. Proc. Soc. exp. Biol., N.Y. 98, 744.

Jensen, K. E. (1956). Influenza. Diagnostic Procedures for Virus and Rickettsial Diseases, 2nd ed. New York: APHA.

Moskowitz, M. \& Calvin, M. (1952). On the components and structure of the human red cell membrane. Exp. Cell Res. 3, 33.

NETER, E. (1956). Bacterial hemagglutination and hemolysis. Bact. Rev. 20, 166.

SPRINGER, G. F. (1963). Enzymatic and nonenzymatic alterations of erythrocyte surface antigens. Bact. Rev. 27, 191. 